\title{
Biofertilizer Impacts on Cassava (Manihot Esculenta Crantz) Cultivation: Improved Soil Health and Quality, Igbariam, Nigeria
}

\section{Ayodele A Otaiku ${ }^{1 *}$, Mmom $\mathrm{PC}^{2}$ and Ano $\mathrm{AO}^{3}$}

${ }^{1}$ Doctoral Student, Faculty of Social Science, Department of Geography and Environmental Management, University of Port Harcourt, Rivers State, Nigeria ${ }^{2}$ Faculty of Social Science, Department of Geography and Environmental Management, University of Port Harcourt, Choba, Port Harcourt, Rivers State, Nigeria ${ }^{3}$ National Root Crops Research Institute, Umudike Umuahia, Abia State, Nigeria

*Corresponding author: JAyodele A Otaiku, Doctoral Student, Faculty of Social Science, Department of Geography and Environmental Management, University of Port Harcourt, Choba, Port Harcourt, Rivers State, Nigeria.
Received Date: December 06, 2019

Published Date: December 16, 2019

\section{Abstract}

Cassava crop cultivation microbiome impacts by microbial biofertilizer is an integral function of the agro-ecology, its evolution (yield, soil health and quality) for sustainable agriculture. Increased yield and nutrient bioavailability powered by co-inoculation of microbial consortia adaptability to the soil ecology. Biofertilizer solves the traceability problem of chemical farm inputs, suitability and nutrient use efficiency as an integral function of the rhizosphere microbiome 'tailor' integrated soil fertility management that improves micronutrient and macronutrient via plant microbe interactions for soil health quality and crop degradation management. Mycorrhizal spp mutualistic symbiosis with plant roots satisfies the crop nutrients requirements. Aspergillus spp, Bacillus spp and Clostridium spp in the biofertilizer enhances potassium solubilization, a major challenge in cassava crop nutrition development of the biomass and mineralization. Soil organic matter improvement as a function of biofertilizer application help management of carbon sequestration and climate vulnerabilities.

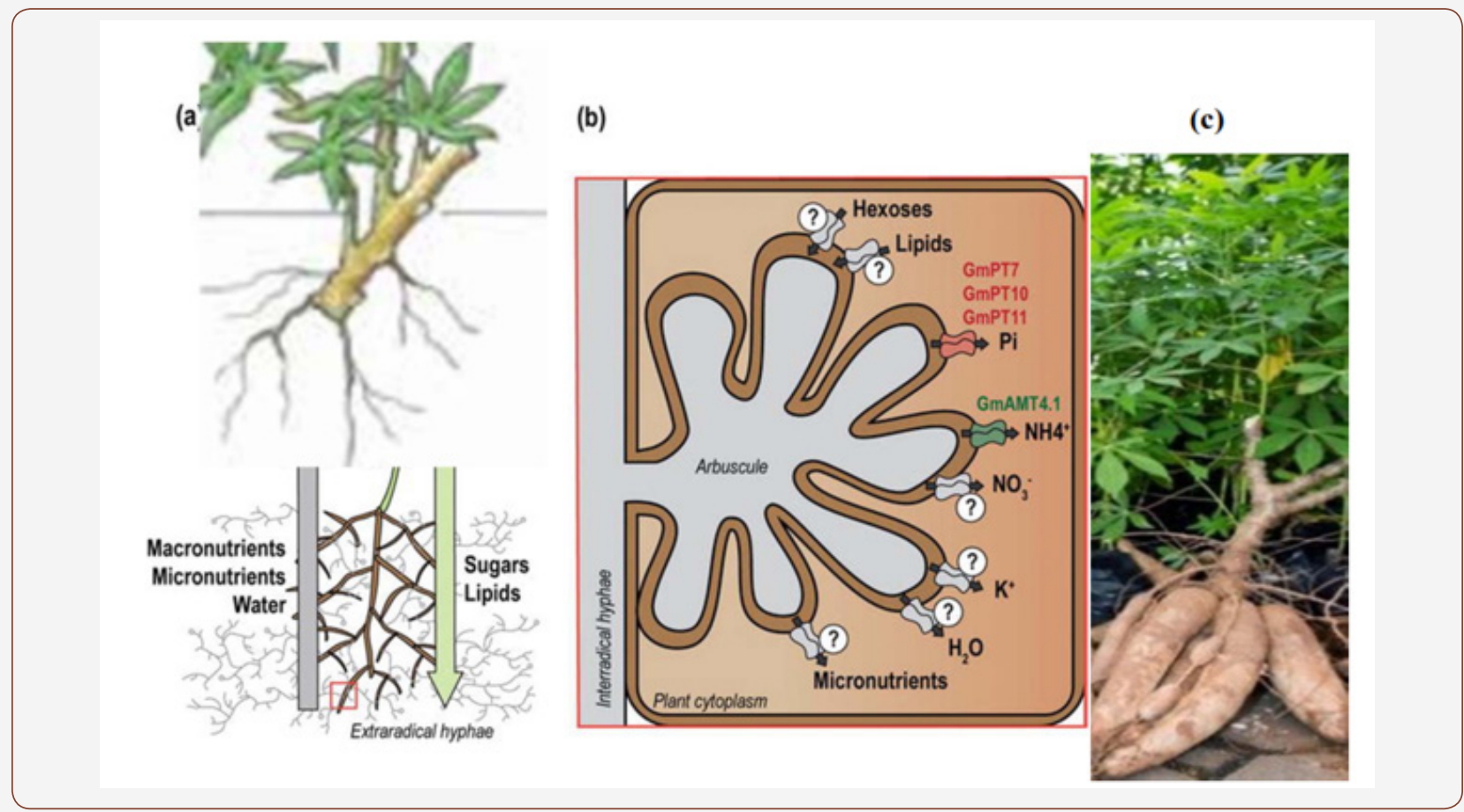

Keywords: Biofertilizer; Plant microbe interactions; Sustainable Food systems; Soil fertility; Climate change; Crop nutrient efficiency; Rhizosphere; Soil health and quality; Cassava (manihot esculenta crantz) 


\section{Introduction}

\section{Cassava cultivation constraints}

Many diseases are caused by pathogens, whose damage symptoms appear on the leaves, stems and storage roots [1] during cassava cultivation. The common diseases of cassava are cassava mosaic disease, cassava bacterial blight, cassava anthracnose disease, cassava bud necrosis and root rot. Some of these diseases attack the leaves and stems of cassava plants while others attack the storage roots [2]. Cassava mosaic disease is caused by the African cassava mosaic virus which occurs inside the leaves and stems and causes yield reductions of up to 90 percent [3]. Economical damage by diseases, pests and weeds of cassava is relatively moderate, although white flies can be a menace in some regions, if the problem is not identified early, and remedial action not implemented in a timely manner (Figure 1). Correct identification of the pest and an understanding of its behaviour, including its most vulnerable stages would provide insights into its management affects crops yield and development. Care must be then taken if pesticide application is contemplated, since there is the likelihood of high residual levels remaining in the product after harvest if an inappropriate formulation is not used.

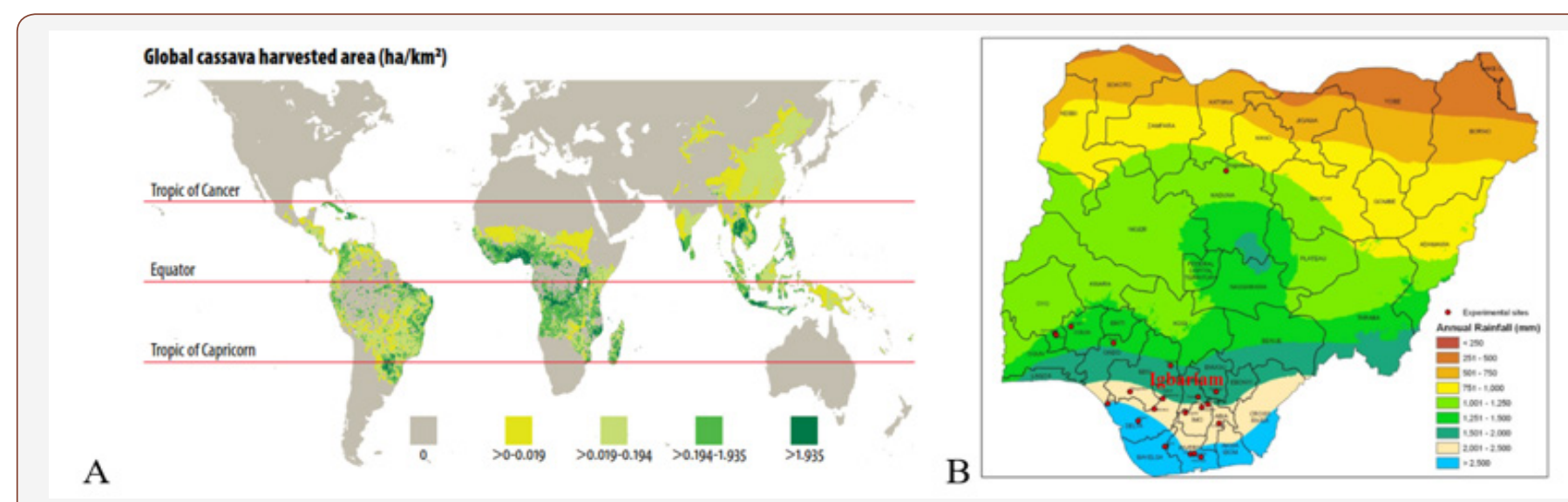

Figure 1: Geographic distribution of crop areas, yields and physiological types and cassava field trial site agro ecology humid forest (Igbariam, Anambra state, Nigeria) adapted from Monfreda et al., 2008 (A) adapted from Yomeni et al., 2010 (B).

Biopesticides can exert fungicidal, insecticidal, or nematocidal action via the microbial inoculate in the biofertilizer, a combination of them and possibly other auxiliary functions such as bird and mammal repellents or herbicides. According to recent classifications [4,5]. Bio-control action is due to multiple synergic mechanisms, generally including: i) production of antibiotics and other secondary metabolites (e.g., phenazines by Pseudomonas spp., lipopeptides by Bacillus spp., and hydrocyanic acid by Rhizobia); and ii) secretion of lytic and defense enzymes (e.g., chitinases, glucanases, peroxidases, polyphenol oxidases, and phenylalanine ammonia lyases produced by Trichoderma, Fusarium, Rhizoctonia, Serratia, Streptomyces and Bacillus strains) [6,7]. The drawback of using living microorganisms is that their efficacy is often unpredictable under changing field conditions, and their fitness is reduced by the presence of an indigenous microbiota difficult to displace by non-native microorganisms $[7,8]$. Additionally, the antagonistic interactions occurring in formulations containing more than one microbial species limit their potential in integrated pest management strategies $[9,10]$.

\section{Biofertilizer formulation}

Table 1: Categorization of general goals for agro-ecosystems.

\begin{tabular}{|c|c|c|}
\hline \multirow{3}{*}{ Goal Type } & General Goal & Key Controlling Variables \\
\hline \multirow{3}{*}{ Economic Viability } & High productivity & Genetic potential, weather, soil, management, economics \\
\cline { 2 - 3 } & Low cost of production & Yield potential*, input requirements*, input costs \\
\cline { 2 - 3 } & Low production risk & Market variation, production variation* \\
\hline \multirow{3}{*}{ Stewardship } & Preservation of productive land & Soil, climate, management \\
\cline { 2 - 3 } & Healthy animals & Feed quantity and quality*, disease \\
\cline { 2 - 3 } & High quality food and fiber & Chemical or microbial contamination*, composition* \\
\hline \multirow{2}{*}{ Social } & Viable local communities & Population size, economic viability, economic diversification \\
\cline { 2 - 3 } & Viable industry, institutions, and infrastructure & Profitability, size and resilience of industry \\
\hline \multirow{3}{*}{ Environment } & Clean water & Climate, soil, management \\
\cline { 2 - 3 } & Clean air & Climate, soil, management \\
\cline { 2 - 3 } & Wildlife habitat & Climate, soil, management \\
\hline
\end{tabular}

*Variables also influenced by soil proper. 
A key advantage of beneficial microorganisms is to assimilate phosphorus for their own requirement, which in turn available as its soluble form in sufficient quantities in soil. Pseudomonas, Bacillus, Micrococcus, Flavobacterium, Fusarium, Sclerotium, Aspergillus and Penicillium have been reported to be active in the solubilisation process [11]. A phosphate-solubilizing bacterial strain Micrococcus sp. has polyvalent properties including phosphate solubilization and siderophore production [12]. Similarly, two fungi Aspergillus fumigatus and A. Niger were isolated from decaying cassava peels were found to convert cassava wastes by the semi-solid fermentation technique to phosphate biofertilizers [13]. Aspergillus, Bacillus and Clostridium are found to be efficient in potassium solubilization in the soil and mobilize in different crops [14]. Mycorrhizal mutualistic symbiosis with plant roots (Figure 2) satisfies the plant nutrients demand [15] which leads to enhance plant growth and development and protect plants from pathogens attack and environmental stress [16]. Pseudomonas aeruginosa has been shown to withstand biotic and abiotic stresses [17]. Paul \& Nair [18] found that P. fluorescens MSP-393 produces osmolytes and salt-stress induced proteins that overcome the negative effects of salt. Microbial inoculants genera in the OBD-Biofertilizer are isolated using the growth media in Table 1 from different agro biowaste and inoculated into the composted biofertilizer.

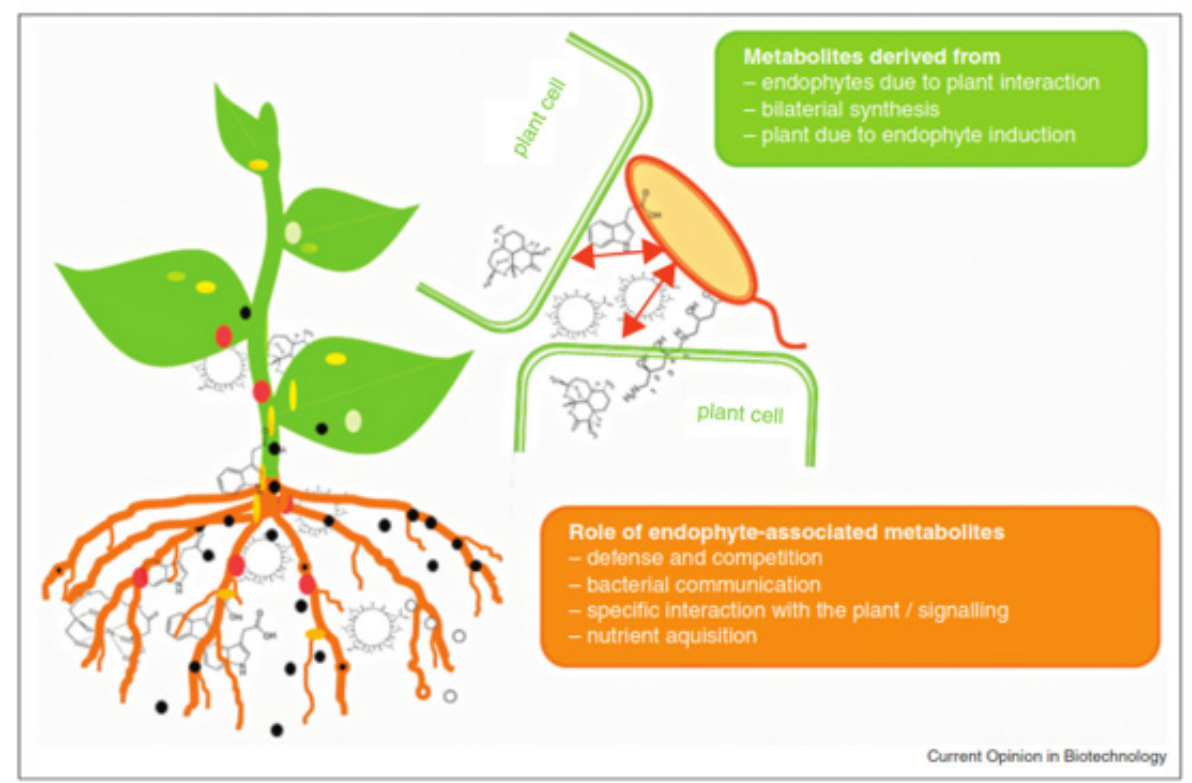

Figure 2: Schematic overview showing the different types of plant-endophyte interactions leading to the synthesis of metabolites, which are in many cases not produced by the macro- or micro symbiont alone or in different quantities, adapted from Sessitsch et al., 2014.

\section{Climate change and soil biological health}

It is commonly observed that applying only $\mathrm{N}$ or $\mathrm{N}+\mathrm{P}$ can lead to a decline in particulate organic matter ( $>53 \mathrm{~m}$ fraction) and soil biological activity (soil respiration, microbial biomass $\mathrm{C}$ and $\mathrm{N}$ ). These however improved significantly by moving towards balanced application through the addition of NPK or NPK+ organics [19]. Also, actual field studies on microbial diversity and activity are few. Contrary to a hypothesis that leaf litter produced under elevated $\mathrm{CO}_{2}$ and having a high $\mathrm{C}: \mathrm{N}$ ratio would be difficult to decompose, the microorganisms were found to adapt to changing soil carbon input under elevated $\mathrm{CO}_{2}$ and there was no effect on their turnover and behaviour [20]. Expectedly, under 15 elevated $\mathrm{CO}_{2}$, increased immobilization of fertilizer $\mathrm{N}$ by stimulation of mineralization (SMB) of soil organic matter (SOM) nitrogen was observed [21].

Thus, greater microbial demand for $\mathrm{N}(>27 \%)$ was observed under elevated $\mathrm{CO}_{2}[22]$. As warmer temperatures are maintained, the less efficient use of carbon by the microbes causes them to decrease in number, eventually resulting in less carbon dioxide being emitted into the atmosphere [23] via an agricultural soil vis-à-vis a desert soil (warmed in real world over time) attests this reality. Mycorrhizal and $\mathrm{N}_{2}$-fixing relationships are generally enhanced by $\mathrm{CO}_{2}$ enrichment, but effects of warming are highly variable [24]. There are reports proving that soil resistance and resilience is linked to soil biodiversity [25] and 'higher' soil diversity protects the soil against ecosystem malfunctions under stress or disturbance: an 'insurance hypothesis' linked to soil biodiversity [26].

Unfortunately, some African soils lack essential nutrients. In Uganda, Kenya and Tanzania low yield of crops was attributed mainly to poor soil fertility [27]. For instance, $\mathrm{Zn}$ is deficient in most West African soils, especially the lowland areas [28] while plant viable $\mathrm{P}$ is unavailable in the iron-rich tropical soils of Africa due to low $\mathrm{pH}$ and high level of iron and aluminum oxides [29]. The soil lacks $\mathrm{Ca}, \mathrm{Mg}$ and $\mathrm{K}$, and when acidic, has a high level of free $\mathrm{Mn}$, which is toxic to crops. Buhmann, et al. [30], some South African soils are deficient in $\mathrm{K}$ and $\mathrm{P}$, making it unsuitable for cultivation. Africa has lower fertilizer consumption when compared to other regions of the world. In 2002, sub-Saharan Africa had about $8 \mathrm{~kg} / \mathrm{ha}$ of fertilizer consumption which increased to $12 \mathrm{~kg} /$ ha in 2010 and $18 \mathrm{~kg} / \mathrm{ha}$ in 2013 (Sommer et al., 2013). This is far below that of other regions of the world such as North America, South Asia, and 
East Asia and Pacific which were estimated at $127.9 \mathrm{~kg} / \mathrm{ha}, 151.8$ and $337.0 \mathrm{~kg} / \mathrm{ha}$ respectively (World Bank Fertiliser Consumption, 2013).

Sub-Saharan Africa fertilizer market lacks basic infrastructure for sustainability, efficient pricing and competition (Sommer et al., 2013). Biofertilizers should not be misunderstood for organic fertilizers such as compost, animal manure and plant manure or extracts [31,32]. However, whether the beneficial microbes improve crop accessibility to nutrients [6,33] or replenish soil nutrients (Shridhar, 2012; Thamer et al., 2011), if the overall nutrient condition of crop and soil has been improved, such substances containing the beneficial microorganisms are considered as biofertilizers [32]. The objectives are:

- How biofertilizer functional architecture links system design (microbial inoculant) impacts on the cassava crops nutrient use efficiency.

- $\quad$ To use the outcome indicators (crop yield, soil organic matter) as a determinant of soil health and quality and soil nutrient facility management.

- How the microbial inoculant impacts on the integrated soil management?

- What are the indicators of soil quality?

\section{Methodology}

\section{Biofertilizer functional models - soil health and quality}

The environment-centric view (biofertilizer impacts) considers function as its effects (biofertilizer). The device-centric view considers function in term of internal parameters of the object (cassava crop physiology). The device-centric functions are the outcome (yield, soil health and quality) of the deployment of the environment centric functions. Eppinger and Browning, 2012 define. Underrating the biofertilizer system architecture of cassava crop cultivation within the agro-ecology, their relationships to crop development, evolution and outcome (yield, soil health and quality). Models are representations of the current understanding of a phenomenon or process of interest [34,35]. Functional models describe the relationship among variables using the simplest description of causal relations possible that still provides a useful description of the process or phenomenon [36]. A functional model would describe the components of the biofertilizer system and how they interact soils and crops cultivation. A mechanistic model would describe the properties of the biofertilizer contained in the components of the soil systems during cultivation. Information is also required on the driving forces that impact the variables controlling outcomes This driving force-outcome-response framework (or pressure-state- response framework) is widely used in environmental assessment [37].

\section{Indicator}

\section{AGROECOSYSTEM SUSTAINABILITY}

\begin{tabular}{|c|c|}
\hline $\begin{array}{c}\text { Environmental } \\
\text { Quality }\end{array}$ & $\begin{array}{c}\text { Agronomic } \\
\text { Sustainability }\end{array}$ \\
$\begin{array}{c}\text { Socio-Economic } \\
\text { Viability }\end{array}$ \\
\hline
\end{tabular}
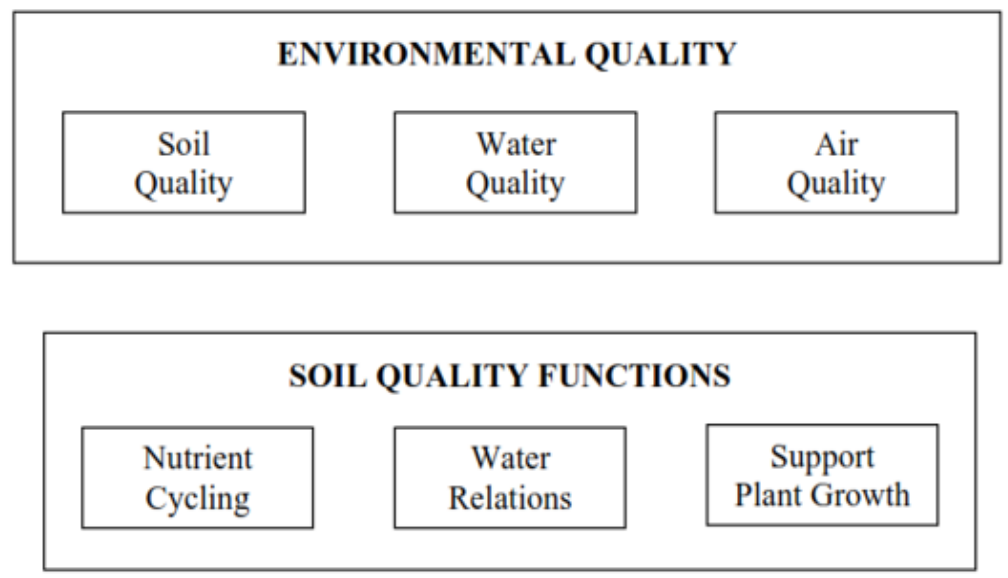

Figure 3: Nested hierarchy of agro-ecosystem sustainability showing the relationship of soil quality to the larger agro-ecosystem adapted from [64].

Biofertilizer is dependent variable is the variable being tested and measured in the cassava (independent variable or manipulated variable) field experiment. The independent variable (cassava crop) effect on the dependent variable is observed and recorded. Indicators can be used to communicate information on driving forces, outcomes, or responses. Driving force indicators communicate information on the causes of a problem, which may provide incentives for appropriate responses or be used to monitor the efficacy of responses. Outcome indicators communicate information on the effects of a problem on a goal. Outcome 
indicators are often slow to respond but are directly related to the issue and are useful for assessment and planning. Response indicators communicate information on the extent to which remedial actions are implemented. Response indicators respond quickly, but their effects are not evident until much later. Indicators may communicate information on level, change or structure [38]. An indicator of structure provides information on industry or policy structures related to driving force (e.g., average farm size) or response (e.g., proportion of farms with an environmental farm plan). Water quality: watersheds with the greatest risk of non-point pollution are identified based on leaching and runoff vulnerability indices calculated for pesticides and nutrients (Figure 3).

For example, vulnerability indices for nutrients are obtained from estimates of excess nutrient levels (manure or commercial fertilizer sources) combined with estimates of leaching (based on precipitation and hydrologic factors) or estimates of run-off, Figure 2 reported by Kellogg et al. [39]. In the United States to develop soil ratings based on measured soil properties for the comparison of land management systems [40] and the approach, soil quality is considered an inherent property of the soil that can be determined from measurable soil attributes [41]. When a soil quality parameter declines below an acceptable limit, an appropriate response is required to increase soil quality. Acceptable limits depend on land use, soil characteristics, landform and climatic conditions. Many potential parameters of soil quality, measurable at various scales of assessment, have been proposed (Table 1). Wander \& Bollero [42] concluded that particulate organic matter, mean wet weight diameter of aggregates, bulk density and penetration resistance may be good indicators of soil quality because they are sensitive to management and environmentally relevant.

Acton \& Gregorich [43] defined soil quality as "the soil's fitness to support crop growth without resulting in soil degradation or otherwise harming the environment". Larson \& Pierce [41] stated that "soil quality describes how effectively soils: 1) accept, hold, and release nutrients and other chemical constituents; 2) accept, hold, and release water to plants, streams and groundwater; 3 ) promote and sustain root growth; 4) maintain suitable biotic habitat; and 5) respond to management and resist degradation". Karlen et al. [44] defined soil quality as "the capacity of a specific kind of soil to function, within natural or managed ecosystem boundaries, to sustain plant and animal productivity, maintain or enhance water and air quality, and support human health and habitation".

\section{Soil quality and health}

Soil quality can be defined as the fitness of a specific kind of soil, to function within its capacity and within natural or managed ecosystem boundaries, to sustain plant and animal productivity, maintain or enhance water and air quality, and support human health and habitation [45]. Soil quality is related to soil functions and soil health concepts views soil as a finite and dynamic living resource [46]. Plant health is clearly a component of soil health but necessarily not of soil quality [47]. Baker \& Cook [48] described the soils in which disease severity or incidence remains low, in spite of the presence of a pathogen, a susceptible host plant and climatic conditions favorable for disease development, as suppressive soils. Soil biota like arbuscular mycorrhizal fungi play a significant role in improving plant nutrition but also act as bioprotectants against pathogens and toxic substances [49]. Thus, there is a considerable degree of overlap in the meaning of soil quality and soil health (Doran, 2002), though soil health perceptions tend to focus more on biotic components of soil [50]. Soil degradation or deterioration in soil health or quality implies loss of the vital functions of soil: (i) providing physical support, water and essential nutrients required for growth of terrestrial plants; (ii) regulation of the flow of water in the environment and (iii) elimination of the harmful effects of contaminants by means of physical, chemical and biological processes, i.e., environmental buffer or filter [38,51]. The quality and health of soil determine agricultural sustainability and environmental quality, which jointly determine plant, animal and human health $[21,52]$.

\section{Results and Discussion}

\section{Biofertilizer - mechanism of action}

The absence of a population of degrading microorganisms can be overcome by the inoculation of the plant rhizosphere with pollutant degrading strains and biosurfactants during crop cultivation via biofertilizer. This approach successful in reducing the levels of benzene, ethylene, toluene xylenes, hydrocarbons, polychlorinated biphenyls and pesticides in polluted environments $[50,53]$ especially in Africa poor soil profile. The rhizosphere is defined as the volume of the soil over which roots have influence, and which is shared with soil bacteria. Plants release exudates in the rhizosphere likely to serve as carbon source for microbes [54]. Consequently, rhizosphere microbes can promote plant health by stimulating root growth via production of plant growth regulators, enhance mineral and water uptake. Some bacteria, especially fluorescent pseudomonads, produce siderophores that have very high affinities for iron as compared to fungal siderophores [55] and can sequester this limited resource from other microflora thereby preventing their growth [56].

Earlier reports have demonstrated the importance of $P$. fluorescens siderophores in disease suppression [57,58], Figure 4. However, many endophytic bacteria are facultative plant colonizers and have to compete well in the rhizosphere before entering the plant [59] and might be therefore equipped with a rich arsenal of metabolites involved in defense as well as in interaction with the plant. Many bacteria with the capacity of colonizing plants utilize the nutrient niche of root surfaces in the rhizosphere and most of them might even actively switch from root surface to endophytic lifestyles [59,60]. These bacteria comprise several well characterized species of Bacillus and Pseudomonas and a number of metabolites, particularly lipopeptides synthesized by non-ribosomal peptide synthesases, have been described to be important for rhizosphere bacteria for antibiosis and for inducing plant defense mechanisms (Figure 5). Biofertilizer characteristics (Table 2) and biosurfactants (Table 3) applied in the filed cassava 
cultivation requires no chemical pesticide. This was as a result of might be cassava plant-associated lifestyle requires adaptation to several niches, in which different metabolites act as signals for interaction (communication) with the plant and host specific plants nutrient and crop protection.

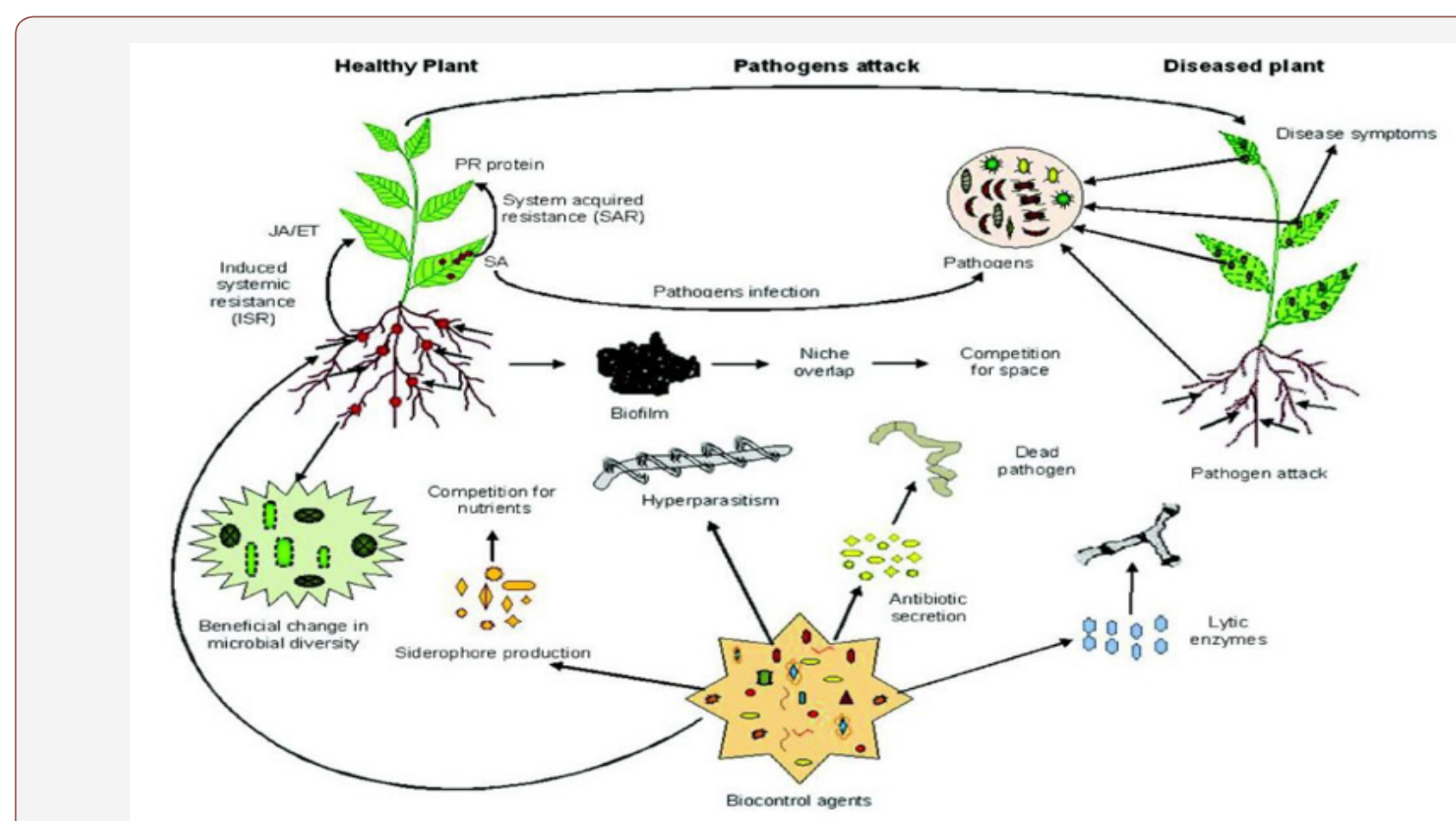

Figure 4: Mechanism of actions implemented by bio-control agents for management of plant diseases adapted from [98].

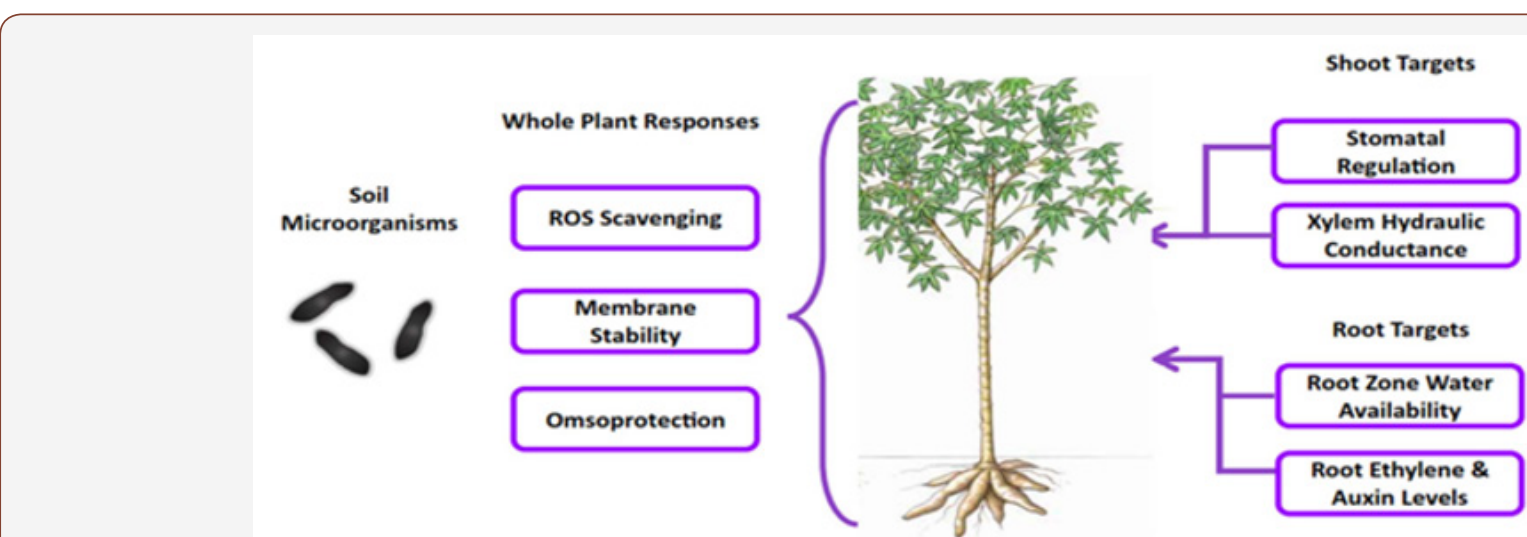

Figure 5: Summary of main key mechanisms targeted by microorganism-based bio stimulants in Table 3 and reactive oxygen species detoxification (ROS detox) enzymes might also ameliorate the plant-induced stress [138].

Table 2: Biofertilizer characteristic as integrated nutrient management during crop cultivation with references.

\begin{tabular}{|c|c|c|c|c|c|}
\hline N/S & Characterization & Definition & Mechanisms & $\begin{array}{c}\text { Crops Appli- } \\
\text { cation }\end{array}$ & References \\
\hline \multirow[t]{2}{*}{1} & \multirow[t]{2}{*}{ Biofertilizer } & \multirow{2}{*}{$\begin{array}{l}\text { A substance which contains live } \\
\text { microorganisms which, when } \\
\text { applied on the seed, plant surface } \\
\text { or the soil, colonizes the } \\
\text { rhizosphere or the interior of the } \\
\text { plant and promotes growth through } \\
\text { increased supply or availability of } \\
\text { primary nutrients for the host plant }\end{array}$} & a. Biological nitrogen fixation & \multirow{2}{*}{$\begin{array}{l}\text { Maize, } \\
\text { Soybean, Rice, } \\
\text { Vegetables, } \\
\text { Plantain, } \\
\text { Horticulture }\end{array}$} & $\begin{array}{c}\text { Vessey [32]; Somers, et al., } \\
\text { [133] }\end{array}$ \\
\hline & & & $\begin{array}{l}\text { b. Utilization of insoluble forms of } \\
\text { phosphorus }\end{array}$ & & $\begin{array}{l}\text { Fuentes-Ramírez \& Cabal- } \\
\text { leroMellado [104] }\end{array}$ \\
\hline \multirow{2}{*}{2} & \multirow{2}{*}{ Phyto stimulator } & \multirow{2}{*}{$\begin{array}{l}\text { Microorganism with the ability to } \\
\text { produce or change the } \\
\text { concentration of growth regulators } \\
\text { such as indole acetic acid, } \\
\text { gibberellic acid, cytokinin's and } \\
\text { ethylene. }\end{array}$} & $\begin{array}{l}\text { a. Production of phytohormones } \\
\text { (auxins, cytokinin's and } \\
\text { gibberellins). }\end{array}$ & & \multirow{2}{*}{$\begin{array}{l}\text { Lugtenberg, et al. [122]; } \\
\text { Somers, et al. [133] }\end{array}$} \\
\hline & & & $\begin{array}{l}\text { b. Decreased ethylene } \\
\text { concentration (in the interior of } \\
\text { the plant). }\end{array}$ & & \\
\hline
\end{tabular}




\begin{tabular}{|c|c|c|c|c|}
\hline \multirow{5}{*}{3} & \multirow{5}{*}{$\begin{array}{l}\text { Biopesticide or } \\
\text { biocontrol agent }\end{array}$} & \multirow{5}{*}{$\begin{array}{l}\text { Microorganisms that promote } \\
\text { plant growth through the control of } \\
\text { phytopathogenic agents, mainly for } \\
\text { the production of antibiotics and } \\
\text { antifungal metabolites. }\end{array}$} & $\begin{array}{l}\text { a. Production of antibiotics } \\
\text { (siderophores, HCN, antifungal } \\
\text { metabolites) }\end{array}$ & \multirow{5}{*}{$\begin{array}{c}\text { Vessey [32]; Somers, et } \\
\text { al. [133]; Chandler et al., } \\
2008 .\end{array}$} \\
\hline & & & $\begin{array}{l}\text { b. Production of enzymes that } \\
\text { degrade the }\end{array}$ & \\
\hline & & & cellular wall of the fungi & \\
\hline & & & c. Competitive exclusion & \\
\hline & & & $\begin{array}{l}\text { d. Acquired and Induced systemic } \\
\text { resistance }\end{array}$ & \\
\hline B & OBD-Biofertilizer & Ditto & ditto & ditto \\
\hline
\end{tabular}

Rhizobium and Bacillus were found to synthesize indole acetic acid (IAA) at different cultural conditions such as $\mathrm{pH}$, temperature and in the presence of agro waste as substrate [61]. Ethylene, unlike other phyto-hormones, is responsible for the inhibition of growth of dicot plants [62]. It was found by Glick et al. [20] that PGPR could enhance the growth of plant by suppressing the expression of ethylene. Interestingly, a model was suggested in which it was shown that ethylene synthesis from 1-aminocyclopropane-1carboxylate (ACC), an immediate precursor of ethylene, which is hydrolyzed by bacterial ACC- deaminase enzyme in the need of nitrogen and carbon source is also one of the mechanisms of induction of conditions suitable for growth, Figure 5. For plantassociated microorganisms introduced as bio-control agents into the rhizosphere or phyllosphere, the population of the microbial bio-control agent declines to background levels when the supporting plant dies, and it must be applied again with the next planting of that crop with the graphic narrative, Figure 5.

\section{Increased yield and nutrient availability}

The use of biofertilizers leads to separate accumulation of $\mathrm{N}, \mathrm{P}$ and $\mathrm{K}$ in the soil, thereby maintaining soil nutrient balance $[33,63]$. Micronutrients ( $\mathrm{Zn}, \mathrm{Fe}, \mathrm{Mn}, \mathrm{Cu}$ and $\mathrm{Mo}$ ) form insoluble complexes in the soil, which are not readily accessible by crops. Mahdi et al. [64], 75\% of applied Zn forms insoluble complexes while plants use only about 1- 4\% of total available $\mathrm{Zn}$ in the soil. However, Rhizobium, Bradyrhizobium, Pseudomonas, Thiobacillus, Saccharomyces, Penicillum and Bacillus can improve the uptake and availability of micronutrients in the soil [31,65]. In Fe immobilized soils, for example, bacteria siderophores solubilize and chelate Fe into complexes that can be easily absorbed by the plant roots [66]. Trichoderma harzianum, a fungal specie, can solubilize minerals such as metallic $\mathrm{Zn}$ and $\mathrm{Mn} 0$ by chelating and reducing mechanisms [67]. Vesicular Arbuscular Mycorrhiza (VAM) are also able to solubilize $\mathrm{Zn}, \mathrm{Fe}, \mathrm{Mn}$, and $\mathrm{Cu}$ in agricultural soil $[68,69]$. This biofertilizer is important in areas experiencing high rate of potassium loss found in West Africa (Nigeria and Guinea Bissau) and East Africa (Burundi, Malawi, Kenya, Swaziland, Uganda and Rwanda) [70]. Another technique used by most plants to arrest $\mathrm{P}$ limiting situation is the plant-fungi symbiotic relationship (ectomycorrhiza and endomycorrhiza).

Plants develop increased root growth by the ex tension of the existing root systems through mycorrhizal association or hormonal stimulation (phyto-stimulation) effect [24]. Here, fungi hyphae are able to mobilize and make $\mathrm{P}$ available to the plants [6]. The arbuscular mycorrhizal fungi (AMF) increase its exploitation of soil nutrients through specialized structures known as vesicles and arbuscules [71]. In addition, $\mathrm{P}$ is mobilized through the changes in sorption balance of soil solution caused by microbial biomass turnover in the rhizosphere. This leads to an increased mobility and uptake of organic P or orthophosphate ions [72]. Though some estimates on critical levels of soil organic matter (SOC) are available (e.g., Greenland et al. (1975)) considered $2 \%$ of SOC as the minimum requirement for maintenance of satisfactory soil aggregate stability and above which no further increases in productivity are achieve [21], the quantitative basis for such thresholds is limited (Loveland and Webb, 2003). Prasad et al. (2003), with particular reference to the Indian agriculture, considered soils with organic carbon (\%) values $<0.5$ as low fertility soils, 0.5 to 0.75 as medium fertility soils and $>0.75$ as high fertility soils. Magdoff (1998) reported potential crop yield increases of $12 \%$ for every $1 \%$ of soil organic matter based on his studies in USA. Soil quality indices are decision tools that effectively combine a variety of information for multi-objective decision making [73].

\section{Enzymes as indicators of organic matter quality and microbial activity}

Soil enzyme assays generally provide a measure of the potential activity, i.e., that encoded in the genotype, but this will rarely be ever expressed. Further, there are at least 500 enzymes and one has decided as to which enzymes would be the best indicators for soil quality [74], Table 4. Three enzymes viz., chitinase, phenol oxidase and phosphomonoesterase, as a group reflect relative importance of bacterial and fungi, as well as the nature of organic matter complex [75]. Phenol oxidase is produced primarily by white rot fungi, and is specific for highly recalcitrant organic matter, such as lignin [76]. Chitinase is a bacterial enzyme which converts chitin, a substance intermediate in its resistance to microbial metabolism produced by fungi and arthropods, into carbohydrates and inorganic nitrogen [77]. Phosphomonoesterase (acid phosphatase) activity is often correlated with microbial biomass [78,79], fungal hyphal length [58] and nitrogen mineralization [80]. Soil quality indicators would be useful to farmers and planners only if we know their critical limits, i.e., the desirable range of values of a given indicator that must be maintained for normal functioning of the soil.

\section{Microorganisms affecting stress tolerance}

Bacteria with the potential to act as bio stimulants (Table 3) have been isolated from a number of ecosystems with saline, alkaline, 
acidic, and arid soils. These bacteria belong to several genera such as Rhizobium, Bradyrhizobium, Azotobacter, Azospirillum, Pseudomonas and Bacillus (Tables 3 \& 4 respectively). Members of these genera have developed strategies to adapt and thrive under adverse conditions [81,82]. Amongst these adaptations, alterations to the composition of the cell wall and the ability to accumulate high concentrations of soluble solutes are common. These allow for enhanced water retention and increased tolerance to osmotic and ionic stress. Cell wall composition is altered through enrichment for exopolysaccharides (EPS) and lipopolysaccharide-proteins and polysaccharide-lipids which form a protective biofilm on the root surface [83,84]. Plant growth-promoting rhizobacteria (PGPR) inoculated soils can ameliorate plant abiotic stress responses and narrated in detail in Figure 4.

Table 3: Microbial Metabolites Processes related to Plant Nutrient in Biofertilizer.

\begin{tabular}{|c|c|c|c|c|c|c|c|}
\hline $\mathrm{N} / \mathrm{S}$ & Genera & Microbe Species & Contribution & Disease Biocontrol & Crops & Metabolites & References \\
\hline \multirow{7}{*}{$\mathrm{A}$} & \multirow{7}{*}{ Bacteria } & Agrobacterium & $\begin{array}{l}\text { increased the } \\
\mathrm{NO}_{3} \text { and } \mathrm{K} \\
\text { uptake }\end{array}$ & Fusarium solan & Potato & $\begin{array}{l}\text { antimicrobial } \\
\text { metabolites } \\
\text { like sidero- } \\
\text { phores, }\end{array}$ & $\begin{array}{l}\text { Idris, et al. } \\
\text { [111] }\end{array}$ \\
\hline & & Azotobacter sp & $\begin{array}{l}\text { consequently, } \\
\text { the shoot and } \\
\text { root }\end{array}$ & Botrytis cinerea & Beans, tomato & $\begin{array}{l}\text { antibiotics, cy- } \\
\text { anides, fungal } \\
\text { cell-wall-de- } \\
\text { grading } \\
\text { enzymes }\end{array}$ & $\begin{array}{c}\text { Lugtenberg } \\
\text { \& Kamilova } \\
\text { [120] }\end{array}$ \\
\hline & & Bacillus sp & $\begin{array}{c}\text { dry weights by } \\
22 \text { to } 33 \text { percent } \\
\text { and }\end{array}$ & F. oxysporum & & $\begin{array}{l}\text { and gaseous } \\
\text { products } \\
\text { including } \\
\text { ammonia. }\end{array}$ & $\begin{array}{l}\text { Bertrand, et } \\
\text { al. [92] }\end{array}$ \\
\hline & & Pseudomonas sp. & $\begin{array}{l}6 \text { to } 21 \text { percent, } \\
\text { respectively }\end{array}$ & Alternaria spp & Roots, leaves & $\begin{array}{l}\text { Phenazines, } \\
\text { pyrrolnitrin, } \\
\text { pyoluteorin }\end{array}$ & $\begin{array}{c}\text { Srivastava } \\
\text { and Shalini, } \\
2008\end{array}$ \\
\hline & & Rhizobium sp & & Sclerotium spp & $\begin{array}{c}\text { rstop on } \\
\text { leaves, oot rot } \\
\text { and stem rot }\end{array}$ & $\begin{array}{l}\text { and cyclic } \\
\text { lipopeptides } \\
\text { like viscosin- } \\
\text { amide. }\end{array}$ & \\
\hline & & Streptomyces sp & & $\begin{array}{l}\text { Colletotrichum linde- } \\
\text { muthianum }\end{array}$ & Beans & $\begin{array}{l}\text { Pseudobactin } \\
\text { and pyoverdin. }\end{array}$ & Hillel [110] \\
\hline & & Enterobacter & & & & $\begin{array}{l}\text { Pyoverdine, } \\
\text { pyochelin and } \\
\text { its precursor } \\
\text { salicylic acid } \\
\text { chitinase and } \\
\text { laminase. }\end{array}$ & \\
\hline \multirow{5}{*}{ B. } & \multirow{5}{*}{ Bacteria } & Pseudomonus putida & $\begin{array}{l}\text { Denitrification, } \\
\text { methanogenesis, } \\
\text { sulfidogenesis } \\
\text { diseases and } \\
\text { as therapeutic } \\
\text { agents }\end{array}$ & $\begin{array}{l}\text { Hydrocarbon Pollutants } \\
\text { [ Benzene, anthracene, } \\
\text { hydrocarbons, PCBs] }\end{array}$ & $\begin{array}{l}\text { biological } \\
\text { remediation } \\
\text { synoptic } \\
\text { interaction of } \\
\text { fermentative } \\
\text { and acetogenic } \\
\text { bacteria, with } \\
\text { methnogens or }\end{array}$ & $\begin{array}{l}\text { Oxygenease } \\
\text { and per- } \\
\text { oxidases, } \\
\text { pseudomicelle } \\
\text { formation }\end{array}$ & $\begin{array}{l}\text { Prescott, et } \\
\text { al. [126]; } \\
\text { Glazer \& } \\
\text { Nikaido, } \\
\text { [107]; } \\
\text { Kapley, et al. } \\
\text { [115] }\end{array}$ \\
\hline & & Pseudomonas aerogenosa & \multirow{4}{*}{$\begin{array}{l}\text { Degrade hydro- } \\
\text { lysable tannins, } \\
\text { diseases and } \\
\text { as therapeutic } \\
\text { agents }\end{array}$} & $\begin{array}{l}\text { Agricultural/agro-indus- } \\
\text { trial wastes }\end{array}$ & $\begin{array}{l}\text { mineralization } \\
\text { by amphipath- } \\
\text { ic molecules }\end{array}$ & $\begin{array}{c}\text { Plasmids, } \\
\text { glycolipids, } \\
\text { phospholipids, } \\
\text { lipoproteins }\end{array}$ & $\begin{array}{l}\text { Bhatta et } \\
\text { al., 2012; } \\
\text { Nitiema et } \\
\text { al., 2010, }\end{array}$ \\
\hline & & \multirow{3}{*}{ Pseudomonas fluorescens } & & Antimicrobial activity & $\begin{array}{l}\text { Decrease } \\
\text { surface and } \\
\text { interfacial } \\
\text { tension }\end{array}$ & $\begin{array}{l}\text { lipopeptides } \\
\text { and polymeric } \\
\text { compounds }\end{array}$ & $\begin{array}{c}\text { Ray [130] } \\
\text { Hamzah, et } \\
\text { al. [108] }\end{array}$ \\
\hline & & & & Biofouling degradation & $\begin{array}{l}\text { Decrease } \\
\text { surface and } \\
\text { interfacial } \\
\text { tension }\end{array}$ & $\begin{array}{l}\text { Reduction } \\
\text { of interfacial } \\
\text { tension }\end{array}$ & $\begin{array}{l}\text { Chaillan, et } \\
\text { al. [94] }\end{array}$ \\
\hline & & & & Antiviral activity & & Rhamnolipid & $\begin{array}{l}\text { Bhatia \& } \\
\text { Ichhpujani, } \\
2005\end{array}$ \\
\hline
\end{tabular}




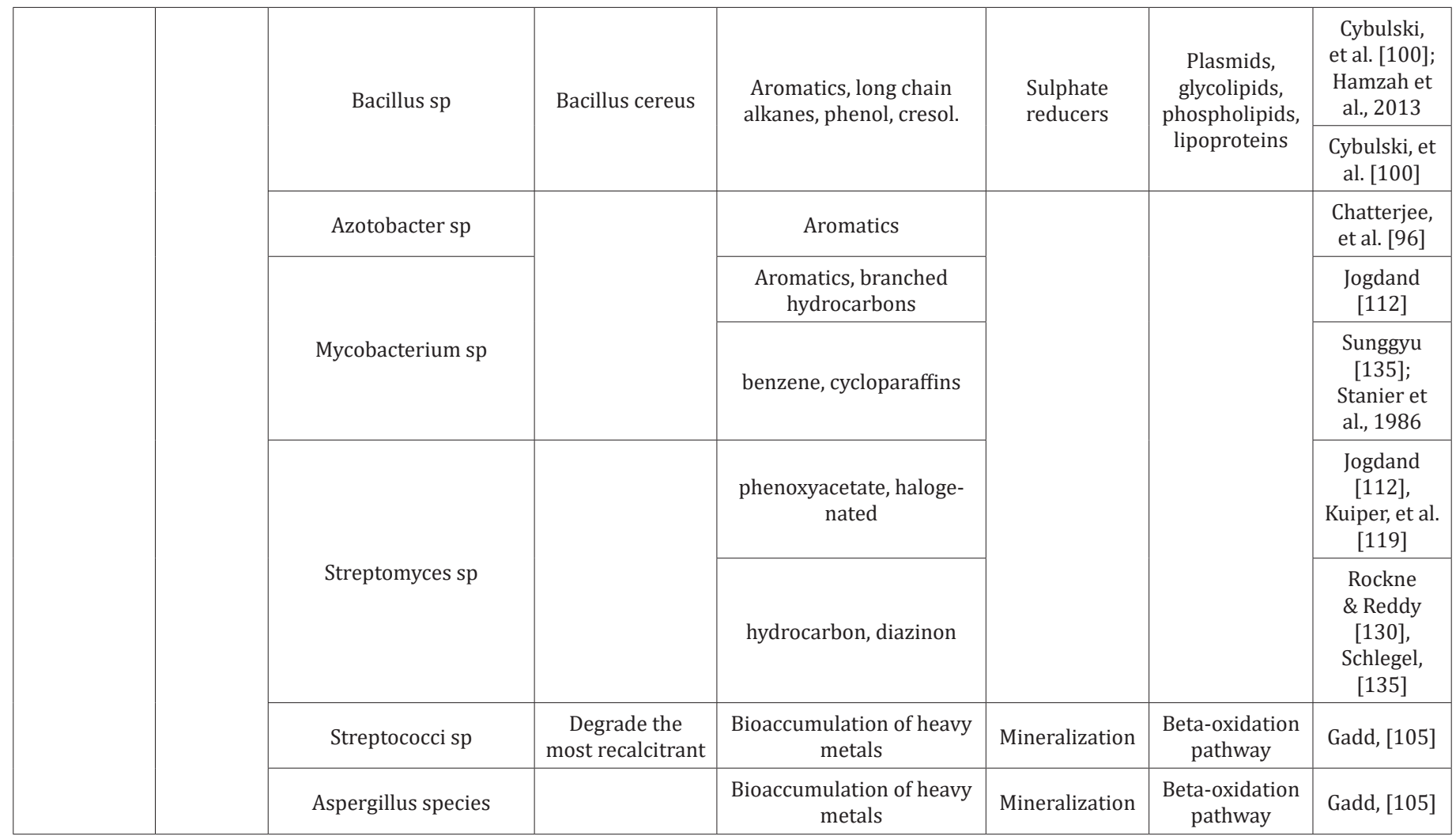

Table 4: Key microbial metabolic processes related to plant nutrition.

\begin{tabular}{|c|c|}
\hline Authors & Index Used/Proposed \\
\hline Andrews, et al. [85] & Indices based on parameters related to entrance of water and plant growth \\
\hline Bastida, et al, [38] & $\begin{array}{l}\text { Microbiological index of soil degradation - dehydrogenase, water soluble carbohydrates, urease, water soluble } \\
\text { carbon and respiration }\end{array}$ \\
\hline Beck [86] & EAN - more enzyme activities (dehydrogenase, phosphatase, protease and amylase) \\
\hline Dilly and Blume, 1990 & As many as ten parameters \\
\hline Doran and Parkin [102] & Index based on sustainable production, environmental quality and human and animal health \\
\hline Doran and Parkin [102] & $\begin{array}{l}\text { Soil quality index = function of (food and fibre production, erosivity, groundwater quality, surface water quality, air } \\
\text { quality and food quality) }\end{array}$ \\
\hline Kandeler and Eder [79] & Simple indices - quotients between enzymatic activity and microbial biomass \\
\hline Kang, et al. [114] & $\begin{array}{l}\text { Microbial index of soil (CHECK) based on microbial biomass } \mathrm{C} \text { and } \mathrm{N} \text {, potentially mineralizable } \mathrm{N} \text {, soil respiration, } \\
\text { bacterial population, mycorrhizal infection, and dehydrogenase and phosphatase activities }\end{array}$ \\
\hline Karlen, et al. [73] & $\begin{array}{l}\text { Soil quality index based on four sour functions: ability of soil to accommodate water entry, retain and supply water } \\
\text { to plants, resist degradation and support plant growth }\end{array}$ \\
\hline Klein and Paschke [117] & $\begin{array}{l}\text { Total/active fungal and bacteria ratio - the ratio of total to active fungal plus bacterial biovolumes is divided by the } \\
\text { ratio of the active fungal to bacterial biovolume }\end{array}$ \\
\hline Parr, et al. [125] & $\begin{array}{l}\text { Soil quality index based on different functions: soil properties, potential productivity, environmental factors, human } \\
\text { and animal health, erodibility, biological diversity, food quality and safety and management inputs }\end{array}$ \\
\hline Parr, et al. [125] & $\begin{array}{c}\text { Soil quality index = function of (soil properties, potential productivity, environmental factors, human/animal health, } \\
\text { erodibility, biological diversity, food quality/safety and management input }\end{array}$ \\
\hline Puglisi, et al. [128] & Soil alteration index \\
\hline Stefanic, et al. [88 & Biological index of soil fertility based on activity of two enzymes - dehydrogenase and catalase \\
\hline Trasar-cepeda et al.,1998; & Indices/equations based on parameters that reflect the total content of $\mathrm{N}$ or organic $\mathrm{C}$ \\
\hline Harris, et al. [109] & $\begin{array}{l}\text { Soil quality index based on three soil functions: ability to resist soil erosion, provide plant nutrients and provide a } \\
\text { favorable root environment }\end{array}$ \\
\hline Velasquez, et al. [139] & $\begin{array}{l}\text { General indicator of soil quality based on abundance of } 17 \text { groups of macrofauna, eight soil chemical properties (ex- } \\
\text { tractable } \mathrm{P} \text {, total P, exchangeable } \mathrm{K}, \mathrm{Mg} \text {, Ca, Na and pH, six physical properties (bulk density, real density, porosity, } \\
\text { moisture content, shear strength, penetration resistance, soil morphological features and organic C fractions }\end{array}$ \\
\hline
\end{tabular}

\section{Soil quality indices}

Soil quality indices are decision tools that effectively combine a variety of information for multi-objective decision making [73].
A number of soil quality and fertility indices have been proposed [85-88], none identifies state of soil degradation that affects its functionality. Bastida et al. [38], building on the approach of Andrews et al. [85], suggested microbiological degradation index. 
Scholars (Table 5) have appreciated and recommended the use of soil quality indices, reservations about their utility have also been expressed. Many a times the concepts associated with soil quality are used in close association with the concepts of sustainability, leading to a degree of confusion and inappropriate use of the term

Table 5: Key microbial metabolic processes related to plant nutrition. soil quality [89] Table 6. Even though the importance of evaluation of soil quality is being increasingly realized, there is yet no global consensus on how this should be defined. While the notion of soil quality includes soil fertility, soil productivity, resource sustainability and environmental quality [90-115].

\begin{tabular}{|c|c|c|c|c|c|}
\hline \multirow{5}{*}{ Element } & Biochemical Process & Microbial Genes & Soil Enzymology Literature & $\begin{array}{c}\text { Culture-Independent } \\
\text { References }\end{array}$ & $\begin{array}{c}\text { Culture-Dependent } \\
\text { References }\end{array}$ \\
\hline \multirow{5}{*}{ Nitrogen } & Nitrogen fixation & nifD, nifH, nifK & & $\begin{array}{c}\text { Reganold et al., 2010; } \\
\text { Xue et al., 2013 }\end{array}$ & Bremer, et al. 1990 \\
\cline { 2 - 6 } & $\begin{array}{c}\text { Protein depolymer- } \\
\text { ization }\end{array}$ & apr, npr, sub & Mader et al., 2002 & Rasche et al., 2014 & Kohler, et al. [118] \\
\cline { 2 - 6 } & Urea catabolism & ureA, ureB, ureC & $\begin{array}{c}\text { Dick et al., 1988; Bowles et } \\
\text { al., 2014 }\end{array}$ & $\begin{array}{c}\text { Reganold et al., 2010; } \\
\text { Fierer et al., 2012, Xue et } \\
\text { al., 2013 }\end{array}$ & Kohler, et al. [118] \\
\hline \multirow{5}{*}{ Phosphorous } & $\begin{array}{c}\text { Phosphate ester } \\
\text { cleavage }\end{array}$ & $\begin{array}{c}\text { phoA, phoD, phoX, } \\
\text { ACPase, glpQ } \\
\text { ushA, appA, phy, } \\
\text { phyB }\end{array}$ & $\begin{array}{c}\text { Mader et al., 2002; Gar- } \\
\text { cia-Ruiz et al., 2008 }\end{array}$ & Fraser et al., 2015 & Kohler, et al. [118] \\
\cline { 2 - 6 } & $\begin{array}{c}\text { Phosphonate break- } \\
\text { down }\end{array}$ & phnJ, phnX & Bergkemper et al., 2016 & $\begin{array}{c}\text { Schmalen berger, et al. } \\
\text { [131] }\end{array}$ \\
\hline \multirow{2}{*}{ Sulfur } & Sulfate ester cleavage & aslA, asfA & Garcia-Ruiz et al., 2008 & $\begin{array}{c}\text { Schmalenberger et al } \\
\text { [131] }\end{array}$ & Kertesz \& Mirleau, 2004 \\
\cline { 2 - 6 }
\end{tabular}

Table 6: Ecological functions of soil $(F A O, 1995)$ and their indicators.

\begin{tabular}{|c|c|}
\hline Ecological Functions of Soil & Indicators of Proper Functioning \\
\hline Production function & High levels of crop yields and incomes \\
\hline Biotic environmental & High levels of species richness and functional dominance of \\
\hline function/living space function & beneficial organisms - high levels of crop yields and incomes and high-quality food and habitation \\
\hline $\begin{array}{c}\text { Climate-regulative function/storage } \\
\text { function }\end{array}$ & High levels of carbon stocks and slow rates of greenhouse gas emissions \\
\hline Hydrologic function & Adequate availability of water/reduced risks floods \\
\hline Waste and pollution control C-function & High levels of crop yields and incomes and high-quality food and habitation \\
\hline
\end{tabular}

\section{Conclusion}

In Nigeria and developing countries analysis of physical, chemical and biological characteristics of soil simultaneously is required to evaluate sustainability/ unsustainability of different management practices, most studies in developing countries have looked at physical and chemical characteristics only. Methodology of assessment of soil quality or soil health are still not in place for agro-ecology for crops microbiomes integrated soil nutrient management [116-132]. Biofertilizer accentuate the capacity of a soil to function by the improvement of the soil organic matter and designate cassava agro-ecology as 'suppressive' soils, Figure2 [133140].

\section{Acknowledgement}

None.

\section{Conflict of Interest}

No conflict of interest.

\section{References}

1. Miskito M, Braima J, Nnodu E, Legg J, Wydra K, et al. (2000) Disease Control in Cassava Farms. Wordsmithes Printers, Lagos, IITA, pp. 1-15.
2. Olugbenga O. Ade Oluwa, Ofoso Budu, Brian Ssebunya (2011) Research Institute of Organic Agriculture, Switzerland.

3. IITA (2008) Starting a Cassava Farm - IPM Field Guide for Extensions Agents. Technical Leaflet No.6 In: New Perspectives and Approaches in Plant Growth-Promoting Rhizobacteria Research. pp. 329-339.

4. Czaja K, Góralczyk K, Strucinski P, Hernik A, Korcz W, et al. (2015) Biopesticides -towards increased consumer safety in the European Union. Pest Manag Sci 71(1): 3-6.

5. Olson S (2015) An analysis of the biopesticide market now and where it is going. Outlook Pest Manag. Ortíz-Castro, Randy Hexon Angel Contreras-Cornejo, Lourdes 26(5): 203-206.

6. Leahy J, Mendelsohn M, Kough J, Jones R, Berckes N (2014) Biopesticide oversight and registration at the U.S. environmental protection agency. In: Coats (Ed.), Biopesticides: State of the Art and Future Opportunities. ACS symposium series American Chemical Society, Washington, pp. 3-18.

7. Parnell JJ, Berka R, Young HA, Sturino JM, Kang Y, et al. (2016) From the lab to the farm: an industrial perspective of plant beneficial microorganisms. Front Plant Sci 7: 1110.

8. Neeraja C, Anil K, Purushotham P, Suma K, Sarma P, et al. (2010a) Biotechnological approaches to develop bacterial chitinases as a bioshield against fungal diseases of plants. Crit Rev Biotechnol 30(3): 231-241.

9. Gadhave KR, Hourston JE, Gange AC (2016) Developing soil microbial inoculants for pest management: can one have too much of a good thing? J Chem Ecol 42(4): 348-356. 
10. Xu XM, Jefries P, Pautasso M, Jeger MJ (2011) Combined use of bio-control agents to manage plant diseases in theory and practice. Phytopathology 101(9): 1024-1031.

11. Pindi PK, Satyanarayana SDV (2012) Liquid microbial consortium- a potential tool for sustainable soil health. J Biofertil Biopest 13: 1-4.

12. Dastager SG, Deepa CK, Pandey A (2010) Isolation and characterization of novel plant growth promoting Micrococcus sp NII-0909 and its interaction with cowpea. Plant Physiol Biochem 48(12): 987-992.

13. Ogbo FC (2010) Conversion of cassava wastes for biofertilizer production using phosphate solubilizing fungi. Bioresour Technol 101(11): 41204124.

14. Mohammadi K, Yousef Sohrabi Y (2012) Bacterial Biofertilizers for sustainable crop production: A review. J Agric Biol Sci 7(5): 307-316.

15. Kogel KH, Franken P, Huckelhovenl R (2006) Endophyte or parasitewhat decides? Curr Opin Plant Biol 9(4): 358-363.

16. Lamabam PS, Gill SS, Tuteja N (2011) Unravelling the role of fungal symbionts in plant abiotic stress tolerance. Plant Signal Behav 6(2): 175-191.

17. Pandey PK, Yadav SK, Singh A, Sarma BK, Mishra A, et al. (2012) CrossSpecies Alleviation of Biotic and Abiotic Stresses by the Endophyte Pseudomonas aeruginosa PW09. J Phytopathol 160(10): 532-539.

18. Paul D, Nair S (2008) Stress adaptations in a plant growth promoting Rhizobacterium (PGPR) with increasing salinity in the coastal agricultural soils. J Basic Microbiol 48(5): 1-7.

19. Manna MC, A Swarup, RH Wanjari, HN Ravankar, B Mishra, et al. (2005) Long term effect of fertilizer and manure application on soil organic carbon storage, soil quality and yield sustainability under sub-humid and semi-arid tropical India. Field Crops Res 93: 264-280.

20. Van Ginkel JH, Gorissen A (1998) In situ decomposition of grass roots as affected by elevated atmospheric carbon dioxide. Soil Sci Soc Am J 62: 951-958.

21. Gorissen A, Cotrufo MF (1999) Elevated carbon dioxide effects on nitrogen dynamics in grasses, with emphasis on rhizosphere processes. Soil Sci Soc Am J 63, 1695-Haberern J (1992) Viewpoint: a soil health index, J Soil Water Conserv 47(6).

22. Williams MA, Charles W Rice Clenton E Owensby (2001) Nitrogen competition in a tall grass prairie ecosystem exposed to elevated carbon dioxide. Soil Sci Soc Am J 65: 340-346.

23. Allison, S. D, Wallenstein MD,Bradford MA (2010) Soil-carbon response to warming dependent on microbial physiology. Nature Geoscience 3: 336-340.

24. Pritchard SG (2011) Soil organisms and global climate change. Plant Pathology 60(1): 82-99.

25. Garbeva P, Veen VJA, Elsas VJD (2004) Microbial diversity in soil: Selection of microbial populations by plant and soil type and implications for disease suppressiveness. Annu Rev Phytopathol 42: 243-270.

26. Yachi S, Loreau M (1999) Biodiversity and ecosystem productivity in a fluctuating environment: The insurance hypothesis. Proc National Academy of Sciences 96(4): 1463-1468.

27. Keino L, Baukya F, Ngetich W, Otinga AN, Okalebo JR, et al. (2015) Nutrients Limiting Soybean (glycine max I) growth in acrisols and ferralsols of Western Kenya. PLoS ONE 10(12): 1-20.

28. Abe SS, Buri MM, Issaka RN, Kiepe P,Takatsuki T (2010) Soil fertility potential for rice production in West African Lowlands. Japan Agricultural Research Quarterly: JARQ 44(4): 343-355.

29. De Valerla AW, Bake, A (2016) Micronutrient management for improving harvests, human nutrition, and the environment Scientific Project, Assigned by Food and Business Knowledge Platform. Wageningen: Wageningen University.

30. Buhmann C, Beukes D, Turner, D (2006) Plant nutrient status of soils of the Lusikisiki area, Eastern Cape Province. South African Journal of Plant and Soil 23(2): 93-98.
31. Ahsan ML, Ali A Ahmed I (2012) Biofertiliser a highly potent alternative to chemical fertilizers: Uses and prospects. Journal of Chemical Engineering and Biological Science 6(4): 10-23.

32. Vessey JK (2003) Plant growth promoting rhizobacteria as biofertilizers. Plant Soil 255(2): 571-586.

33. Egamberdiyeva D (2007) The effect of plant growth promoting bacteria on growth and nutrient uptake of maize in two different soils. Applied Soil Ecology 36(2-3): 184-189.

34. Addiscott TM (1993) Simulation modelling and soil behaviour. Geoderma 60(1): 15-40.

35. Yaalon DH (1994) On models, modeling, and process understanding. Soil Science Society of America Journal 58: 1276.

36. Dörner D (1996) The logic of failure. Metropolitan Books, New York, NY. $222 \mathrm{pp}$.

37. McRae T, Smith CAS, Gregorich LJ (2000) Environmental sustainability of Canadian agriculture: report of the agri-environmental indicator project. Agriculture and Agri-Food Canada, Ottawa, ON, pp. 1-232.

38. Bastida F, Moreno JL, Hernandez T, Garcia C (2006) Microbiological degradation index of soils in a smiarid climate. Soil Biology and Biochemistry 38(12): 3463-3473.

39. Kellogg RL, Wallace S, Alt K, Gos DW (1997) Potential priority watersheds for protection of water quality from nonpoint sources related to agriculture. $52^{\text {nd }}$ Annual SWCS Conference. Toronto.

40. Karlen D L, Andrews S S, Doran J W (2001) Soil quality: Current concepts and applications. Advances in Agronomy 74: 1-40.

41. Larson WE, Pierce FJ (1994) The dynamics of soil quality as a measure of sustainable management. In J W Doran, DC Coleman, DF Bezdicek, BA Stewart, eds. Defining soil quality for a sustainable environment. Soil Science Society of America, Madison, WI, USA 35: 37 - 51.

42. Wander MM, Bollero G (1999) Soil quality assessment of tillage impacts in Illinois. Soil Science Society of America Journal 63(4): 961-971.

43. Acton DF, Gregorich LJ (1995) The health of our soils - towards sustainable agriculture in Canada. Centre for Land and Biological Resources Research, Research Branch, Agriculture and Agri-Food Canada, Ottawa, ON.

44. Karlen DL, Mausbach MJ, Doran JW, Cline RG, Harris RF, et al. (1997) Soil quality: a concept, definition and framework for evaluation. Soil Science Society of America Journal 61: 4-10.

45. Arshad MA, Martin, S (2002) Identifying critical limits for soil quality indicators in agroecosystems. Agriculture, Ecosystems and Environment 88(2): 153-160.

46. Doran JW, Zeiss MR (2000) Soil health and sustainability: managing the biotic component of soil qualify, Applied Soil Ecology 15: 3-11.

47. Karlen D L, Mausbach MJ, Doran JW, Cline RG, Harris RF, et al. (1997) Soil quality: a concept, definition, and framework for evaluation. Soil Science Society of America Journal 61: 4-10.

48. Baker KF, Cook RJ (1974) Biological Control of Plant Pathogens. American Phytopathology Society, San Franscico, pp. 433.

49. Jeffries P, Gianinazzi S, Perotto S (2003) The contribution of arbuscular mycorrhizal fungi in sustainable maintenance of plant health and soil fertility. Biol Fertil Soils 37: 1-16.

50. Johnson DL, Maguire KL, Anderson DR, McGrath SP (2004) Enhanced dissipation of chrysene in planted soil: the impact of a rhizobia inoculum. Soil Biology \& Biochemistry 36: 33-38.

51. Costanza R, Norton BG, Haskell BD (1992) Ecosystem Health: New Goals for Environmental Management. Island Press, Washington, DC.

52. Doran JW (2002) Soil health and global sustainability: translating science into practice. Agriculture, Ecosystems and Environment 88(2): 119-127.

53. Yousaf S, Ripka K, Reichenauer T, Andria V, Afzal M, et al. (2010a) Hydrocarbon degradation and plant colonization by selected bacterial 
strains isolated from Italian ryegrass and birds foot trefoil. Journal of Applied Microbiology 109(4): 1389-1401.

54. Olson PE, KF Reardon, EAH Pilon-Smits (2003) Ecology of rhizosphere bioremediation. In: S.C. McCutcheon and JL Schnoor (Ed.) Phytoremediation: transformation and control of contaminants. John Wiley and Sons, Inc, Hoboken NJ, pp. 317-353.

55. O Sullivan DJ, O Gara F (1992) Microbiol Rev 56: 662-667.

56. Kuc J (1995a) Phytoalexins, stress metabolism and disease resistance in plants. Annu Rev Phytopathol 33: 275-297.

57. Costa JM, Loper JE (1994) Mol Plant-Microbe Interact 7: 440-448 pp.

58. Leong SA, Expert D (1989) Plant - Microbes Interactions, Molecular and Genetic Perspectives, McGraw-Hill, New York 3: 62-83.

59. Compant S, Clement C, Sessitsch A (2010) Plant growth-promoting bacteria in the rhizo-and endosphere of plants: their role, colonization, mechanisms involved and prospects for utilization. Soil Biol Biochem 42: 669-678.

60. Rosenblueth M, Martinez-Romero E (2006) Bacterial endophytes and their interactions with hosts. Mol Plant-Microbe Interact 19: 827.

61. Sudha M, Gowri RS, Prabhavati P, Astapriya P, Devi SY, et al. (2012) Production and optimization of indole-acetic-acid by indigenous micro flora using agro waste as substrate. Pakistan J Biological Sci 15(1): 3943.

62. Ansari MW, Trivedi DK, Sahoo RK, Gill SS, Tuteja N (2013) A critical review on fungi mediated plant responses with special emphasis to Piriformospora indica on improved production and protection of crops. Plant Physiol Biochem 70: 403-410.

63. Adesemoye A,Torbert H, Kloepper J (2008) Enhanced plant nutrient use effidency with PGPR and AMF in an integrated nutrient management system. Can J Microbiol 54(10): 876-886.

64. Joylata laishram, KG Saxena RK, Maikhuri, KS Rao (2012) Soil Quality and Soil Health: A Review International Journal of Ecology and Environmental Sciences 38(1): 19-37.

65. Adeleke R A,Cloete TE, Bertrand A ,Khasa DP (2010) Mobilisation of potassium and phosphorus tram iron ore by ectomycorrhizal fungi. World Journal of Microbiology and Biotechnology 26(10): 1901-1913.

66. Mathew A, Eberl L, Earlier AL (2014) A novel siderophore-independent strategy of iron uptake in the genus Burkholderia. Molecular Microbiology 91(4): 805- 820.

67. Altomare C, Norvell W,Bjorkman T, Harman G (1999) Solubilisation of phosphates and miaonutrients by the plant-growth-promoting and biocontrol fungus Trichoderma harzianum Rifai1 295-22. Appl Environ Microbiol 65(7): 2926-2933.

68. Martino E, Perotto S, Parsons R, Gadd GM (2003) Solubilization of insoluble inorganic zinc compounds by ericoid mycorrhizal fungi derived from heavy metal polluted sites. Soil Biology and Biochemistry 35(1): 133- 141.

69. Pal S, Singh H, Farooqui A, Rakshit A (2015) Fungal biofertilisers in Indian agriculture: Perception, demand and promotion. Journal of Ecoriendly Agriculture 10(2): 101-113.

70. Hartemink AAA, Lungu O, Naimi M, Okoth P, Smaling E, et al. (2012) African soils: Their productivity and profitability of fertilizer use. In: J Kihora, D Fatondji, JW Jones, G Hoogenboom, R Tabo, Bationo A (Eds.), Improving soil fertility recommendation in Africa using decision support system for agro-technology transfer, New York, pp. 19-42.

71. Leigh J, Hodge A, Fitter AH (2009) Arbuscular mycorrhizal fungi can transfer substantial amounts of nitrogen to their host plant from organic material. New Phytologist 181(1): 199-207.

72. Adeleke R, Nwangburuka C, Oboirien B. (2017) Origins, roles and fate of organic acids in soils: A review. South African Journal of Botany 108: 393-406.

73. Karlen DL, Stott DE (1994) A framework for evaluating physical and chemical indicators of soil quality. In: Doran, J, Coleman DC, Bezdicek DF, Stewart BA (Editors) Defining Soil Quality for a Sustainable Environment. Soil Science Society of America, Madison, WI 35: 53-72.
74. Schloter M, Dilly 0, Munch JC (2003) Indicators for evaluating soil quality. Agriculture, Ecosystems and Environment 98(1-3): 255-262.

75. Giai C, Boerner REJ (2007) Effects of ecological restoration on microbial activity, microbial functional diversity, and soil organic matter in mixedoak forests of southern Ohio, USA. Applied Soil Ecology 35: 281-290.

76. Carlisle MJ, Watkinson SC (1994) The Fungi. Academic Press, NY, pp. 482.

77. Hanzlikova A, Jandera A (1993) Chitinase and changes of microbial community in soil. Folio Microbiol.38(2): 159-160.

78. Clarholm M (1993) Microbial biomass P, Labile P, and acid phosphatase activity in the humus layer of a spruce forest, after repeated additions of fertilizer. Biology and Fertility of Soils 8: 1281-1333.

79. Kandeler E, Eder G (1993) Effect of cattle slurry in grassland on microbial biomass and on activities of various enzymes. Biology and Fertility of Soils 16: 249-254.

80. Decker KLM, Boener REJ, Morris SJ (1999) Scale-dependent patterns of soil enzyme activity in a forested landscape. Canadian Journal of Forest Research 29: 232-241.

81. Selvakumar G, Joshi P, Mishra PK, Bisht JP, Gupta HS (2009) Mountain aspects influence the genetic clustering of psychrotolerant phosphate solubilizing Pseudomonads in the Uttarkhand Himalayas. Curr Microbiol 59(4): 432-8.

82. Upadhyay SK, Singh DP Saikia R (2009) Genetic diversity of plant growth promoting rhizobacteria from rhizospheric soil of wheat under saline conditions. Curr Microbiol 59(5): 489-96.

83. Sandhya V, Ali AS, Grover M, Reddy G, Venkateswarlu B (2009) Alleviation of drought stress effects in sunflower seedlings by the exopolysaccharides producing Pseudomonas putida strain GAP-P45. Biol Fertil Soils 46(1): 17- 26

84. Zahran HH (1999) Rhizobium-legume symbiosis and nitrogen fixation under severe conditions and in an arid climate. Microbiol Mol Biol Rev 63(4): 968-89.

85. Andrews SS, Karlen DL, Mitchell JP (2002) A comparison of soil quality indexing methods for vegetable production systems in Northern California. Agriculture, Ecosystems and Environment 90(1): 25-45.

86. Bationo, Beck T (1984) Methods and application of soil microbiological analysis at the Landesanstalt fur Bodenkultur and Pfanzenbau (LBB) in Munich for the determination of some aspects of soil fertility. In: Nemes MP, Kiss S, Papacostea P, Stefanic C, Rusan M (eds.), Fifth Symposium on Soil Biology, pp. 13-20.

87. Karlen DL, Gardner JC, Rosek MJ (1998) A soil quality framework for evaluating the impact of CRP. J prod Argic 11: 56-60.

88. Stefanic F, Ellade G, Chirnageanu J (1984) Researches concerning a biological index of soil fertility. In: Nemes MP, Kiss S, Papacostea P, Stefanic C, Rusan M (Eds.), Fifth Symposium on Soil Biology, pp. 35-45.

89. Sojka RE, Upchurch DR (1999) reservations regarding the soil quality concept. Soil Sci Soc Am J 63(5): 1039-1054.

90. Adeleke R, Cloete E, Khasa D (2010) Isolation and identification of iron ore-solubilising fungus. South African Journal of Science 106(9-10): 1-6.

91. Bennet JW, Wunch KG, Faison B D (2002) Use of fungi biodegradation. Manual of environmental microbiology 2002, 2nd ed., ASM Press: Washington, DC, pp. 960-971.

92. Bertrand TF, Fredric T, Robert N (2004) Production and partial characterization of a thermostable amylase from Ascomycetes yeast strain isolated from starchy soil. McGraw-Hill Inc, New York, pp. 53-55.

93. Bezdicek DF, Stewart BA (eds.), Defining soil Quality for a Sustainable Environment, SSSA Special Publication No.35, ASA and SSSA, Madison, WI, pp. 53-72.

94. Chaillana F, Flècheb A, Burya E, Phantavonga Y-hui, Saliot A, et al. (2004) Identification and biodegradation potential of tropical aerobic hydrocarbon-degrading microorganisms. Res. Microb 155(7): 587- 595.

95. Chandrasekaran B, Josephson JR (2000) Function in device representation, Engineering with Computers 16: 162-177. 
96. Chatterjee S, Haldar S, Asakura M, Yamasaki S, Balasubramanian T (2008) Molecular identification and phylogenetic status of marine bacillus associated with coral sediment, showing antibacterial effects against human pathogens. Ann. Microbiol 58(2): 309-312.

97. Chatterjee S, Mukherjee A, Agniswar S, Roy p (2012) Bioremediation of lead by lead resistant microorganisms isolated from industrial sample. Advances in Bioscience and Biotechnology 3: 280-285.

98. Cook RJ, Veseth RJ (1991) Wheat health management. APS Press, St. Paul, MN, pp. 152.

99. Cotter PD, Hill C, Ross RP (2005) Bacteriocins: developing innate immunity for food. Nat Rev Microbiol 3(10): 777-788.

100. Cybulski Z, Dzuirla E, Kaczorek E, Olszanowski A (2003) The influence of emulsifiers on hydrocarbon biodegradation by Pseudomonadacea and Bacillacea strains. Spill Science and Technology Bulletin 8(5-6): pp 503-507.

101. Dilly 0, Blume HP (1998) indicators to assess sustainable land use with reference to soil microbiology. Advances in GeoEcology 31: 29-39.

102. Doran JW, Parkin TB (1994) Defining and assesming soil quality. In: Doran JW, Coleman DC, Bezdieck DF, Stewart BA, (Eds.), Defining Soil Quality for a sustainable environment, Madison, WI, Soil Sci Soc Am 35: 3-21 (special publication).

103. Doran JW, Parkin TB (1996) Quantities indicators of soil quality: a minimum data set. In: Doran JW, Jones AJ (Eds.), Methods for assessing Soil quality, SSSA Special Publication N0.49, SSSA, Madison, WI, pp. 2537.

104. Eppinger SD, Browning TR (2012) Design structure matrix methods and applications, MIT press, Fuentes-Ramírez LE, Caballero-Mellado J (2006) Bacterial biofertilizers. In: Z.A. Siddiqui (Ed). PGPR: Biocontrol and Biofertilization. Springer, Netherlands, pp. 143-172.

105. Gadd GM (1986) The uptake of heavy metals by fungi and yeasts: the chemistry and physiology of the process and applications for biotechnology, in Immobilisation of Ions by Bio-sorption, ed. By Eccles H and Hunt S. Ellis Horwood Ltd, Chichester, pp. 135-147.

106. Gil-Sotres F, Trasar-Cepeda C, Leiros MC, Seoane S (2005) different approaches to evaluating soil quality using biochemical properties. Soil Biology and Biochemistry 37(5): 877-887.

107. Glazer, AG Nikaldo H (2007) Microbial Biotechnology Fundamentals of Applied Microbiology 2nd Ed Gordon R (1994) Bioremediation and its Application to Exxon Valdez Oil Spill in Alaska.

108. Hamzah A, Rabu A, Azmy RFHR, Yussoff NA (2010) Isolation and characterization of bacteria degrading Sumandak and South Angsi oils. Sains Malaysiana 39(2): 161-168.

109. Harris RF, Karlen DL, Mulla DJ (1996). A conceptual framework for assement and management of soil quality and health. In: Doran JW, Jones AL (Eds.), Methods for assessing soil quality. ASA and SSSA, Madison, WI 49: 61-82.

110. Hillel D, (2005) Thermal properties and processes. In: Encyclopedia of Soils in the Environment. D. Hillel JH, Hatfield DS, Powlson C, Rosenzweig KM, Scow MJ, Singer, DL Sparks Eds 4: 156-163.

111. Idris EES, Iglesias DJ, Talon M (2007) Tryptophan dependent production of indole-3-acetic 267 acid (IAA) affects level of plant growth promotion by Bacillus amyloliquefaciens FZB42. Mol 268 Plant Microbe Interact 20(6): 619-626.

112. Jogdand SN (1995) Environmental biotechnology, 1st Edition, Himalaya Publishing House, Bombay, India, pp. 104120.

113. Kandeler E, Gerber H (1988) Short-term assay of soil urease activity using colorimetric determination of ammonium. Biology and Fertility of Soils 6: 68-72.

114. Kang GS, Beri V, Sidhu BS, Rupela OP (2005) A new index to assess soil quality and sustainability of wheat-based cropping systems. Biology and Fertility of Soils 41: 389-398.

115. Kapley A, Purohit HJ, Chhatre S, Shanker R, Chakrabati T, et al. (1999) Osmotolerance and hydrocarbon degradation by a genetically engineered microbial consortium. Biosour. Technol 67(3): 241-245.
116. Karlen DL (1992) Soil and crop management effects on soil quality indicators. American. J Alternative Agric 7: 48-55.

117. Klein DA, Paschke MW (2000) A soil microbial community structural -functional index: the microscopy-based total/active/active fungal/ bacterial (TA/AFB) bio volumes ratio. Applied Soil Ecology 14(3): 257268.

118. Kohler J, Caravaca F, Carrasco L, Roldan A (2007) Interactions between a plant growth-promoting rhizobacterium, an AM fungus and a phosphate-solubilising fungus in the rhizosphere of Lactuca sativa. Appl Soil Ecol 35: 480-487.

119. Kuiper I, Lagendijk EL, Bloemberg GV, Lugtenberg BJJ (2004) Rhizoremediation: a Beneficial Plant-Microbe Interaction. Mol Plant Microbe Interact 17(1): 6-15.

120. Lugtenberg B, Kamilova F (2009) Plant-Growth-Promoting Rhizobacteria. Annual Review of Microbiology 63: 541-556.

121. Lugtenberg B, Kamilova F (2009) Plant-Growth-Promoting Rhizobacteria. Annual Review of Microbiology 63: 541-556.

122. Lugtenberg BJJ, Chin A Woeng TFC, Bloemberg GV (2002) Microbeplant interactions: principles and mechanisms. Anton. Leeuw 81: 373383.

123. Mahdi SS, Hassan G, Samoan S, Rather H, Dar SA, et al. (2010) Biofertilizers in organic agriculture. Journal Phytology 2(10): 42-54.

124. Oldal B, Jevcsák I, Kecskés M (2002) A sziderofortermel o képesség szerepe Pseudomonas-törzsek növénypatogénantagonista hatásának biológiai vizsgálatában. Biokémia 26: 57-63.

125. Parr JF, Papendick RI, Hornick SB, Meyer RE (1992) Soil quality: attributes and relationship to alternative and sustainable agriculture. Am. J. Alternative Agric 7: 5-11.

126. Prescott LM, Harley JP, Klein DA (2002) Microbiology. Fundamentals of applied Microbiology 2: 1012-1014.

127. Prescott MI, Harle JD, Klein DA (2002) Microbiology of Food. $5^{\text {th }}$ Ed. McGraw-Hill Ltd, New York, USA, pp. 964-976.

128. Puglisi E, Nicelli M, Capri E, Trevisan M, Attilo AM (2005) A soil alteration index based on phospholipids fatty acids. Chmosphere 61(11): 1548-1577.

129. Randlett DL et al (1996) Elevated atmospheric carbon dioxide and leaf litter chemistry: Influence on microbial respiration and net nitrogen mineralization. Soil Sci Soc Am J 60: 1571-1577.

130. Ray G (1994) Bioremediation and its application to Exxon Valdez Oil Spill in Alaska. Ray's Environmental Science Web Site Rockne, Karl and Reddy, Krishna (2003). Bioremediation of Contaminated Sites. University of Illinois at Chicago.

131. Schmalenberger A, Hodge S, Bryant A, Hawkesford MJ, Singh BK, Kertesz MA (2008) The role of variovorax and other comamonadaceae in sulphur transformations by microbial wheat rhizosphere communities exposed to different sulphur fertilization regimes. Environ Microbiol 10(6): 1486-1500.

132. Shimomura Y, M Yoshioka, H Takeda, Y Umeda, T Tomiyama (1998) Representation of design object based on the functional evolution process model, Journal of Mechanical Design 120(2): 221-229.

133. Somers E, Vanderleyden J, Srinivasan M (2004) Rhizosphere bacterial signalling: a love parade beneath our feet. Crit Rev Microbiol 30(4): $205-240$.

134. Sparling GP, Schipper LA, Bettjeman W, Hill R (2004) Soil quality monitoring in New Zealand: practical lessons from a 6-year trial. Agriculture, Ecosystems and Environment 104(3): 523-534.

135. Sunggyu L (1995) Bioremediation of polycyclic aromatic hydrocarbon contaminated soil. Journal of Cleaner Production 3: 255.

136. Trasar Cepeda C, Leiros C, Gil Stotres F, Seoane S (1997) Towards a biochemical quality index for soils: an expression relating several biological and biochemical properties. Biology and Fertility of Soils 26: 100-106. 
137. Van Oosten VR, Bodenhausen N, Reymond P, Van Pelt JA, Van Loon LC, et al. (2008) Differential effectiveness of microbial induced resistance against herbivorous insects in Arabidopsis. Molecular Plant-Microbe Interactions 21(7): 919-930.

138. Van Oosten MJ, Olimpia P Stefania De Pascale, Silvia S, Maggio A (2017) The role of biostimulants and bioeffectors as alleviators of abiotic stress n crop plants Chem Biol Technol Agric 4: 5
139. Velásquez E, C Pelosi, D Brunet, M Grimaldi, M Martins, et al. (2007) This ped is my ped: visual separation and NIRS spectra allow determination of the origins of soil macro-aggregates. Pedobiologia 51(1): 75-87.

140. Wander MM, SJ Traina, BR Stinner and SE Peters (1994) Organic and conventional management effects on biologically active soil organic matter pools. Soil Sci Soc Am J 58: 1130-1139. 